\title{
MORPHOLOGICAL VARIABILITY OF THE NANOPLANKTONIC DIATOM THALASSIOSIRA LAEVIS FROM COASTAL WATERS OF PROVINCE OF Buenos Aires (Argentina)
}

\author{
EUGENIA A. SAR ${ }^{1,2^{*}}$ and INÉS SUNESEN ${ }^{1,2}$
}

\begin{abstract}
Summary: Morphological variability of the nanoplanktonic diatom Thalassiosira laevis from coastal waters of Province of Buenos Aires (Argentina). Despite the fact that the genus Thalassiosira was previous and extensively studied including ultrastructural analysis of species found in phytoplanktonic samples collected from marine waters of Argentina, nanoplanktonic species have been frequently overlooked. This paper is devoted to show the morphological variation of Thalassiosira laevis, a nanoplanktonic species collected from marine coastal waters of the Province of Buenos Aires, to compare Argentinean material with those from China, Korea and Brazil described in the literature, and to record it for the first time from Argentina.
\end{abstract}

Key words: Thalassiosira, Thalassiosira laevis, morphological variability, new record for Argentina.

\begin{abstract}
Resumen: Variabilidad morfológica de la diatomea nanoplanctónica Thalassiosira laevis procedente de aguas costeras de la Provincia de Buenos Aires (Argentina). A pesar del hecho de que el género Thalassiosira ha sido previa y extensivamente estudiado incluyendo análisis ultraestructural de especies encontradas en muestras fitoplanctónicas colectadas de aguas marinas de Argentina, las especies nanoplanctónicas han sido frecuentemente pasadas por alto. Este trabajo está dedicado a mostrar la variabilidad morfológica de Thalassiosira laevis, una especie nanoplanctónica de aguas marinas costeras de la Provincia de Buenos Aires, a comparar el material con aquellos procedentes de China, Korea y Brasil descriptos en la literatura y a reportarla por primera vez para Argentina.
\end{abstract}

Palabras clave: Thalassiosira, Thalassiosira laevis, variabilidad morfológica, nuevo reporte para Argentina.

\section{INTRODUCTION}

Taxa belonging to the genus Thalassiosira Cleve emend. Hasle (1973) from Argentinian coastal waters were previously studied including ultrastructural analysis by Lange et al. (1983), Sar \& Ferrario (1987), Ferrario \& Sar (1988), Gayoso (1989), Sar (1996), Sar et al. (2001, 2002, 2011), Sunesen \& Sar (2004) and Sunesen (2007), nevertheless, nanoplanktonic species were frequently overlooked.

Thalassiosira laevis Gao \& Cheng (1992) is a nanoplanktonic species that was erected from

1 División Ficología, Facultad de Ciencias Naturales y Museo, Universidad Nacional de La Plata, Argentina;

2 Consejo Nacional de Investigaciones Científicas y Técnicas, CONICET, Argentina;

*easar@fcnym.unlp.edu.ar seawaters of Xiamem, China and characterized by having most part of the valve surface smooth, with areolae restricted to valve mantle and marginal area of valve surface. Subsequently, the species was reported in marine coastal waters by Li et al. (2013, 2014) from China, and by Park et al. (2016) from Korea, in estuarine waters as unidentified diatom resembling T. profunda by Belcher \& Swale (1986) from Thames River, England, and more recently in sedimentary samples of the Late Holocene and in modern samples of phytoplankton by Garcia \& Mareschi Bissa (2016) from Brazil.

The purpose of this study is to show morphological variation of this nanoplanktonic species frequently found in marine coastal waters from Province of Buenos Aires and to compare it with material analyzed from China, Korea and Brazil. 


\section{Material ANd Methods}

The material studied was collected in coastal waters of the Province of Buenos Aires (Fig. 1). The sampling stations in the Province of Buenos Aires were: San Clemente del Tuyú (36 $26^{\circ} 1^{\prime} 16^{\prime \prime}$

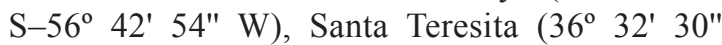
S-56 41' 09" W), La Lucila del Mar (36 $36^{\circ} 39^{\prime} 30^{\prime \prime}$

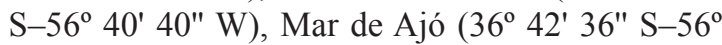
$\left.40^{\prime} 17^{\prime \prime} \mathrm{W}\right)$, Nueva Atlantis ( $36^{\circ} 45^{\prime} 47^{\prime \prime} \mathrm{S}-56^{\circ} 40^{\prime}$ 23" W), Pinamar ( $37^{\circ} 07^{\prime} 22^{\prime \prime}$ S-56 $\left.56^{\circ} 26^{\prime \prime} \mathrm{W}\right)$, Villa Gesell ( $\left.37^{\circ} 16^{\prime} 50^{\prime \prime} \mathrm{S}-56^{\circ} 58^{\prime} 52^{\prime \prime} \mathrm{W}\right)$ and Mar Azul ( $37^{\circ} 20^{\prime} 22^{\prime \prime}$ S-5 $57^{\circ} 01^{\prime} 24^{\prime \prime} \mathrm{W}$ ), and samples were collected from November 1994 to September 2000 and from March 2008 to December 2015. The seawater temperature ranges from $8-24{ }^{\circ} \mathrm{C}$ along the coast and the salinity between $27-32$, occasionally reaching 18 , in the stations from San Clemente to Nueva Atlantis, and from 30-34 in the other three mentioned stations (unpublished data).

Qualitative samples were taken from the surface layer of the water column in the coastal waters with $30 \mu \mathrm{m}$ net hauls and fixed with $4 \%$ formalin. In the laboratory, the preserved samples were rinsed with distilled water to remove salt and preservatives, and then the organic matter was oxidized according to Hasle \& Fryxell (1970) and Prygiel \& Coste (2000). The cleaned material was mounted for light (LM) and scanning electron microscopy (SEM) after Ferrario et al. (1995). Permanent mounts were made with Naphrax (Brunel Microscopes, Chippenham, UK).

The raw and treated samples, slides and stubs material were deposited in the Herbarium (index herbariorum LPC), División Ficología "Dr. Sebastián A. Guarrera", Facultad de Ciencias Naturales y Museo, Universidad Nacional de La Plata, under the numbers LPC 4250 to 4495 , LPC 11001 to 11462 , LPC 13648 to 13685.

Observations and photomicrographs were made with scanning electron microscopes Jeol JSMT 100 and Jeol JSM 6360 LV (JEOL, Tokyo, Japan).

Terminology follows Fryxell \& Hasle (1979), Syvertsen \& Hasle (1982), Ross et al. (1979) and Round et al. (1990). Considering the very small diameter of the analyzed material, fultoportula density was determined following Hasle (1983) calculated as: number of marginal fultoportulae $\cdot 10$ $/ \pi \cdot$ valve diameter.

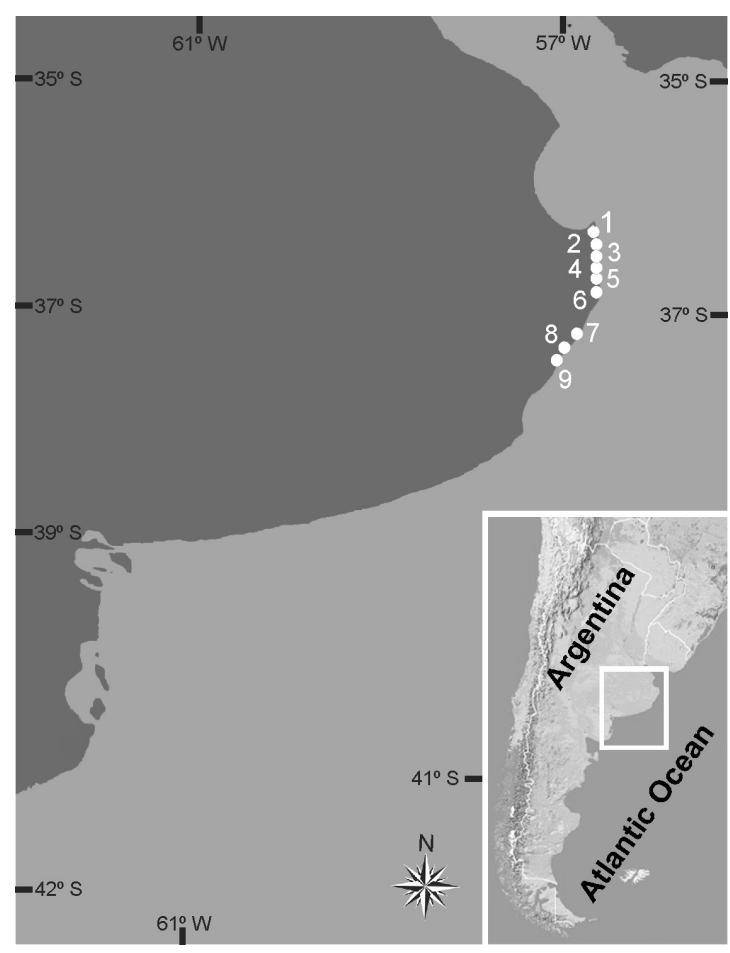

Fig. 1. Map of the marine littoral of Buenos Aires Province showing sampling stations and location of the area in Argentina. 1: San Clemente del Tuyú, 2: Santa Teresita, 3: Mar del Tuyú, 4: La Lucila del Mar, 5: Mar de Ajó, 6: Nueva Atlantis, 7: Pinamar, 8: Villa Gesell, 9: Mar Azul.

\section{Results}

Thalassiosira laevis Gao \&Cheng (Figs 2 A-F, 3 A-E)

References: Gao, Y. \& Z. Cheng 1992: 291, figs. 1-3; Li et al. 2013: 95, fig. 69; Park et al. 2016: 409, fig. 18; Garcia \& Mareschi Bissa 2016: 34, figs 4-16.

The valves are circular. The valve face is flattened to slightly depressed and valve mantle is low and oblique, with unstructured, hyaline rim (Fig. 2 A-C, E, F). Diameter 2.2-6.7 $\mu \mathrm{m}$. Most part of valve surface lacks areolae (Fig. 2 A) or in some specimens presents ghost areolae more or less numerous, radiating to the central or slightly subcentral fultoportula (Fig. 2 B-D). The areolation is limited to the valve mantle and to the margin of the valve face forming two to five rings 

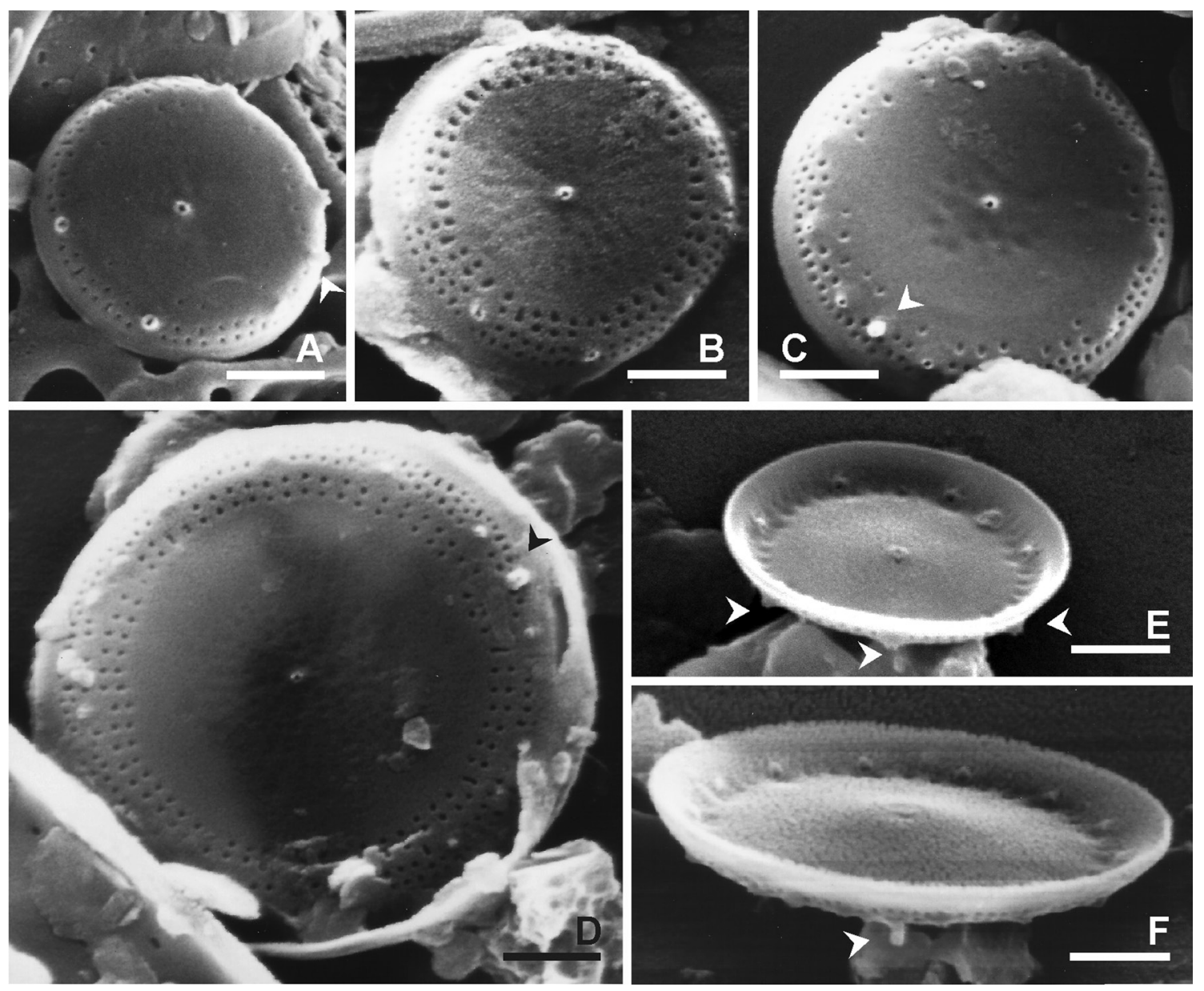

Fig. 2. Thalassiosira laevis. SEM. A-D: Valves in external view. A: Valve showing central part hyaline, external tubes of fultoportulae and rimoportula midway between two fultoportulae (arrowhead), LPC 4284. B: Valve showing central part with numerous ghost areolae, radiating to the central fultoportula, LPC 4364. C: Note scarce number of ghost areolae, bulb-shaped tubes of fultoportulae and cylindric tube of rimoportula (arrowhead), LPC 4304. D: Note five rings of marginal areolae, LPC 4486. E-F. Valves tilted. E. Note external bulb-shaped tubes of the marginal fultoportulae (arrowheads), LPC 11097. F. Note cylindrical external tube of the rimoportula (arrowhead), LPC 4449. Scale bars $=1 \mu \mathrm{m}$, Figs A-F.

of areolae (Fig. 2 A-D). Stria density $50-80$ in 10 $\mu \mathrm{m}$, denser in the mantle than in the valve surface. Areolae have circular to subrectangular external foramina (Fig. 2 A-D) and internal cribra (Fig. 3 $\mathrm{B}, \mathrm{D}, \mathrm{E})$. The central fultoportula has a very short external and internal tube (Figs 2 A-F, 3 A-E) and two internal, operculate, satellite pores (Fig 3 A, $\mathrm{B}, \mathrm{D}, \mathrm{E})$. A marginal ring of fultoportulae, 5-12 per valve, regularly spaced, $6.5-8.5$ in $10 \mu \mathrm{m}$, is placed between the junction of the valve surface and mantle (Fig. 2 A-D). Marginal fultoportulae are slightly different from the central one, with two upper satellite pores also operculate, short cup-shaped inner tubes and short outer bulb-shaped tubes with rimmed pore (Fig. 3 A, B, D, E). A single, sessile, tangential to oblique rimoportula is positioned midway between two fultoportulae (Fig $2 \mathrm{~A}, \mathrm{D})$ or closer to one of them (Fig. 2 C, 3 A, D), somewhat inside the marginal ring (Fig. $3 \mathrm{~A}, \mathrm{D}$ ). Rimoportula has cylindrical external tube and it is internally encircled by a siliceous rim (Fig. 3 A, B, D). The girdle has numerous bands (Fig. 3 C). 

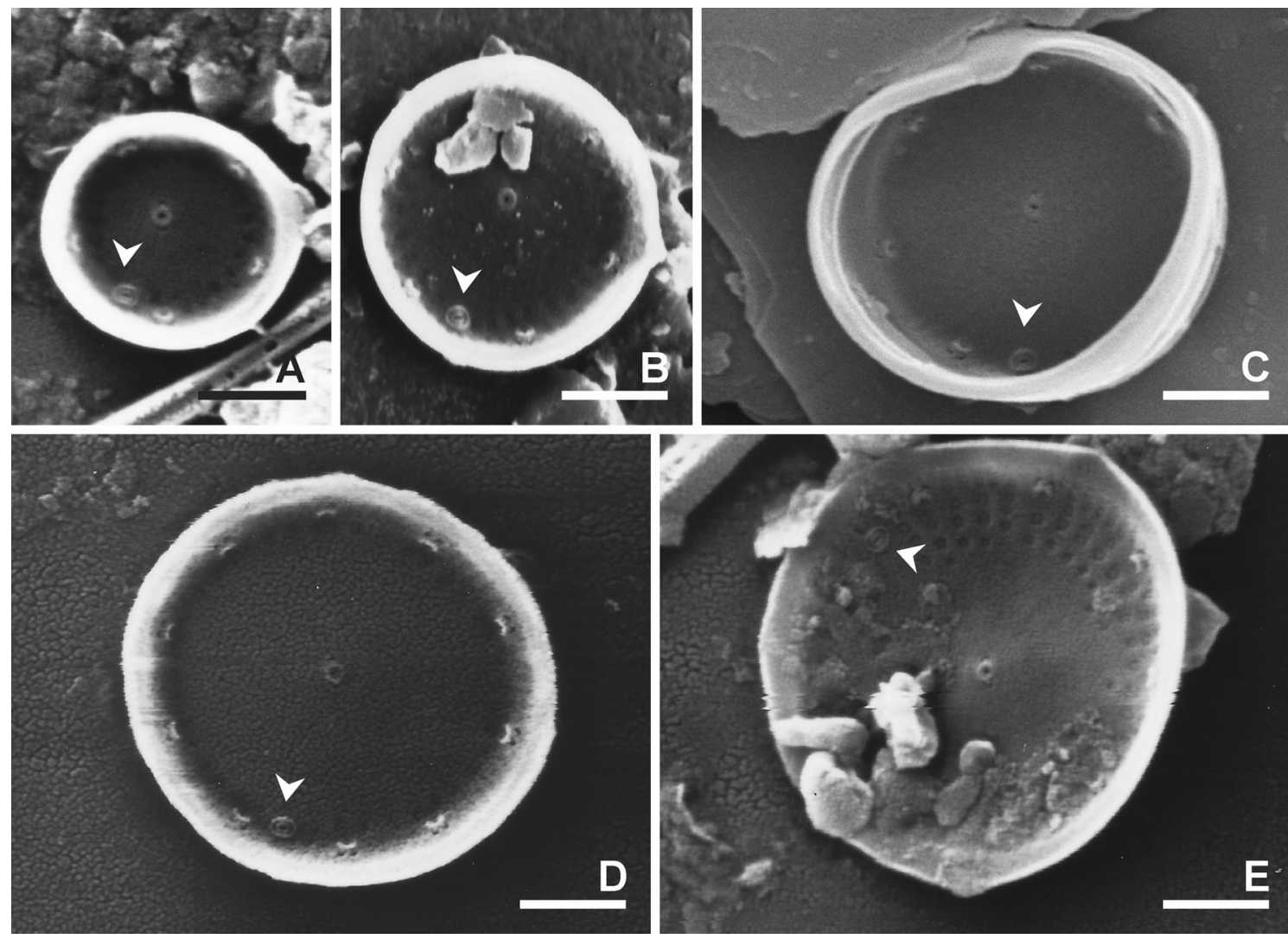

Fig. 3. Thalassiosira laevis. SEM. A-E: Valves in internal view. A: Note slightly subcentral fultoportula with two satellite pores, ring of marginal fultoportulae, and sessile rimoportula closer to one fultoportula, LPC 4363. B, D: Processes pattern, marginal ring of fultoportulae with two operculate satellite pores, and sessile rimoportula encircled by a siliceous rim (arrowhead), LPC 4291 and LPC 4359. C: Valve with numerous girdle bands, LPC 4486. D: Note marginal striae with areola occluded by cribra, LPC 4367. Scale bars $=1 \mu \mathrm{m}$, Figs A-E.

Photographed material: LPC 4284, Pinamar, 26/04/1996; LPC 4291, Villa Gesell, 29/06/1996; LPC 4304, La Lucila del Mar, 11/01/1997; LPC 4359, La Lucila del Mar, 31/07/1998; LPC 4363, La Lucila del Mar, 19/09/1998; LPC 4364, La Lucila del Mar, 19/09/1998; LPC 4367, Villa Gesell, 19/09/1998; LPC 4449, San Clemente del Tuyú, 27/08/2000; LPC 4486, La Lucila del Mar, 27/08/2000; LPC 11097, Santa Teresita, 12/01/2009; LPC 11097, Santa Teresita, $12 / 01 / 2009$.

Distribution in Argentina: Thalassiosira laevis was found in phytoplankton samples in all the stations of the studied area as scarce to common, throughout the year, and it was occasionally found in San Matías Gulf. This is the first record of the species for the Argentinian coastal waters.

\section{Discussion}

Thalassiosira laevis belongs to a small group of nanoplanktonic Thalassiosira species with a central fultoportula, a marginal ring of fultoportulae, and a marginal rimoportula. A comprehensive comparison among a group of species with this fultoportula pattern, which diameter ranges between 2 and $9 \mu \mathrm{m}$, including $T$. laevis, $T$. catharinensis Garcia in Garcia \& Bärwaldt Dutra 


\section{E. A. Sar and I. Sunesen - Morphological variability of Thalassiosira laevis}

(2016), T. profunda (Hendey) Hasle, T. oceanica Hasle, and T. pseudonana Hasle \& Heimdal, was presented by Garcia \& Bärwaldt Dutra (2016) in their Table 1. We do not agree with these authors in reference to the external morphology of the marginal fultoportulae and the single rimoportula of T. laevis. Fultoportulae were described as lacking external tubes, probably based on Garcia \& Mareschi Bissa $(2016$, figs 8, 11) in which the tubes are eroded at the bases, nevertheless, their own figure 16 shows the typical external tubes, very short and with bulb-shaped bases, similar to those pictured by Park et al. (2016, fig. S27) and by us in this study (Figs 2A-C, E). Rimoportula was also described as lacking external tube, nevertheless it opens by a cylindrical tube, larger than those of the fultoportulae as it was shown by Garcia \& Mareschi Bissa (2016, figs 8, 12) and mentioned in the results, Park et al. (2016, figs 18, S25, S27) and this study (Figs 2A, C, D, F).

It may be worthwhile to notice that specimens analyzed in this study $(\mathrm{LM}=63, \mathrm{SEM} \mathrm{n}=69)$ has a slightly narrower diameter range $(2.2-6.5 \mu \mathrm{m})$ than material reported by Li et al. $(2013,2014)$, more similar with described by Gao \& Cheng (1992), Park et al (2016), Garcia \& Mareschi Bissa (2016) and Garcia \& Bärwaldt Dutra (2016); they never showed three distal satellite pores in the marginal fultoportulae, only reported by Garcia \& Mareschi Bissa (2016, figs 14, 15); and the position of rimoportula is variable, closer to one or midway between two fultoportulae.

T. laevis is a morphologically distinctive species with: 1) areolation pattern, restricted to the margin of the valve, 2-5 rings; 2) fultoportula pattern: one central with two satellite pores, and one marginal ring of fultoportulae with short external tubes bulb-shaped at basis, $6.5-8.5$ in $10 \mu \mathrm{m}$; 3) one rimoportula closer to one, or midway between two fultoportulae, with cylindrical external tube; 4) cosmopolitan, living in marine coastal waters and estuarine waters; 5) extinct and extant.

\section{ACKNOWLEDgements}

The research was supported by grants from the Universidad Nacional de La Plata 11/N722, and from the Consejo Nacional de Investigaciones Científicas y Técnicas, PIP0067.

\section{Bibliography}

BELCHER, J. H. \& E. M. F. SWALE. 1986. Notes on some small Thalassiosira species (Bacillariophyceae) from the plankton of the lower Thames and other British estuaries (identified by Transmission Electron Microscopy). Br. Phycol. J. 21: 139-145.

FERRARIO, M. E. \& E. A. SAR. 1988. Marine Diatoms from Chubut (Argentina Republic) Centrales II Thalassiosira. Rev. Bras. Biol. 48: 421-429.

FERRARIO, M. E., E. A. SAR \& S. E. SALA. 1995. Metodología básica para el estudio del fitoplancton con especial referencia a las diatomeas. In: ALVEAL, K., M. E. FERRARIO, E. C. OLIVEIRA \& E. SAR (eds.), Manual de Métodos Ficológicos, pp. 1-23. Universidad de Concepción, Concepción, Chile.

FRYXELL, G. A. \& G. R. HASLE. 1979. The genus Thalassiosira. Species with internal extensions of strutted processes. Phycologia 18: 378-393.

GAO, Y. \& Z. CHENG. 1992. A new species and two new varieties of Thalassiosira. J. Xiamen Univ. Nat. Sci. 31: 291-294.

GARCIA, M. \& D. BÄRWALDT DUTRA. 2016. A new species of nanoplanktonic diatom: Thalassiosira catharinensis (Bacillariophyceae) from Southern of Brazil. Phytotaxa 288: 61-68.

GARCIA, M. \& W. MARESCHI BISSA. 2016. First Record of Talassiosira laevis Gao \& Cheng for the Southern Hemisphere in the Atlantic Ocean. Diatom 32: 33-37.

GAYOSO, A. M. 1989. Species of the diatom Genus Thalassiosira from a Coastal Zone of the South Atlantic (Argentina). Bot. Mar. 32: 331-337.

HASLE, G. R. 1973. Thalassiosiraceae, a new Diatom Family. Norweg. J. Bot. 20: 67-69.

HASLE, G. R. 1983. The marine, planktonic diatoms Thalassiosira oceanica sp. nov. and T. partheneia. J. Phycol. 19: 220-229.

HASLE, G. R. \& G. A. FRYXELL. 1970. Diatoms: cleaning and mounting for light and electron microscopy. Trans. Amer. Microscop. Soc. 89: 469-474.

LANGE, C., R. M. NEGRI \& H. R. BENAVIDES. 1983. Algunas especies del género Thalassiosira (Bacillariophyceae) del Mar Argentino. (Parte 1). Iheringia, Ser. Bot. 31: 9-30.

LI, Y., Q. ZHAO \& S. LÜ. 2013. The genus Thalassiosira off the Guangdong coast, South China Sea. Bot. Mar. 56: 83-110.

LI, Y., Q. ZHAO \& S. LÜ. 2014. Taxonomy and species diversity of the diatom genus Thalassiosira (Bacillariophyceae) in Zhejiang coastal waters, the East China Sea. Nova Hedwigia 99: 373-342.

PARK, J. S., S. W. JUNG, S. D. LEE, S. M. YUN \& J. H. LEE. 2016. Species diversity of the genus 
Thalassiosira (Thalassiosirales, Bacillariophyta) in South Korea and its biogeographical distribution in the world. Phycologia 55: 403-423.

PRYGIEL, J. \& M. COSTE. 2000. Guide Méthodologique pour la mise en ouvre de l'Indice Biologique Diatomées. Agences de l'Eau, Ministère de l'Aménagement du Territoire et de l'Environnement, Direction de l'Eau \& CEMAGREF, France.

ROSS, R., E. J. COX, N. I. KARAYEVA, D. G. MANN, T. B. B. PADDOCK, R. SIMONSEN \& P. A. SIMS. 1979. An amended terminology for the siliceous components of the diatom cell. In: SIMONSEN, R. (ed.), Proceedings of the Fourth Symposium on Recent and Fossil Marine Diatoms. Nova Hedwigia, Beih. 54: 513-533.

ROUND, F. E., R. CRAWFORD \& D. G. MANN. 1990. The Diatoms. Morphology and Biology of the Genera. Cambridge University Press, London.

SAR, E. A. 1996. Flora diatomológica de Bahía San Antonio (Prov. de Río Negro, Argentina) O. Centrales I. Rev. Mus. La Plata (n. s.) 14, Bot. 106: 365-400.

SAR, E. A. \& M. E. FERRARIO. 1987. Novedades sobre la distribución de Thalassiosira curviseriata Takano y T. pacifica Gran et Angst (Bacillariophyceae) en Argentina. Gayana, Botánica 44: 89-91.

SAR, E. A., I. SUNESEN \& C. CASTAÑOS. 2001. Marine diatoms from Buenos Aires coastal waters (República Argentina). I. Thalassiosiraceae. Nova Hedwigia 73: 199-228.
SAR, E. A., I. SUNESEN \& A. S. LAVIGNE. 2002. The diatom genus Thalassiosira: species from the northern San Matías Gulf (Río Negro, Argentina). Nova Hedwigia 74: 373-386.

SAR, E. A., I. SUNESEN, A. S LAVIGNE \& S. LOFEUDO. 2011. Thalassiosira rotula Meunier a heterotypic synonym of Thalassiosira gravida Cleve. Morphological evidence. Diatom Research 26: 109-119.

SUNESEN, I. 2007. Diatomeas de ambientes costeros de la Provincia de Buenos Aires. Análisis taxonómico de los géneros que incluyen especies productoras de floraciones algales nocivas. Tesis doctoral, Facultad de Ciencias Naturales y Museo. Universidad Nacional de la Plata.

SUNESEN, I. \& E. A. SAR. 2004. Thalassiosira fryxelliae nov. spec. (Bacillariophyceae) from Argentinian coastal waters. Bot. Mar. 47: 238-247.

SYVERTSEN, E. E. \& G. R. HASLE. 1982. The marine planktonic diatom Lauderia annulata Cleve, with particular reference to the processes. Bacillaria 5: 243-256.

Recibido el 28 de febrero de 2017, aceptado el 15 de junio de 2017. 